\title{
"Na Cadeia de Sons da Vida": considerações sobre Música Popular e Literatura na obra de Paulo Leminski
}

\author{
Marcelo Sandmann*
}

\section{Resumo:}

Tomando como exemplo a obra do escritor curitibano Paulo Leminski, o presente artigo investiga o lugar ocupado pela música popular na cultura brasileira nas últimas décadas do século $X X$, bem como algumas de suas relações com a produção literária do período.

\section{Palavras-chave:}

Paulo Leminski, Música Popular Brasileira, Poesia Brasileira.

\section{Canção popular brasileira: anos $\mathbf{6 0}$ e $\mathbf{7 0}$}

Em publicação recente, Elos de melodia e letra, que reúne análises semióticas de canções de Caetano Veloso, Chico Buarque e da parceria Tom Jobim e Vinicius de Moraes, Luiz Tatit e Ivã Lopes sintetizam, nos seguintes termos, o lugar que a canção popular acabou por ocupar na vida cultural do Brasil a partir de meados do século $X X$ :

Desde a eclosão do movimento bossa-nova, em 1958, a canção brasileira vem atraindo a atenção, não apenas da forte indústria do entretenimento instalada no país, mas também de boa parte da elite cultural que hoje Ihe reserva o papel artístico e social anteriormente concedido apenas à literatura e às artes eruditas em geral. Essa condição especial não pode evidentemente ser desvinculada dos grandes artistas que emprestaram ou vêm emprestando o seu talento para a criação de um repertório cancional cuja originalidade e qualidade já são reconhecidas em todo o mundo. (TATIT e LOPES, 2008, p. 51)

A canção popular (a música popular), em sua múltipla manifestação, é matéria de amplo interesse. Por sua própria natureza, é realização cara a grande parte da população brasileira, esteja ela concentrada nos centros urbanos, ou dispersa no meio rural, agora definitivamente conectado aos mesmos centros, numa malha cerrada e de trocas várias. Circulando pelos meios de massa, permeia o cotidiano das pessoas, integra os momentos de trabalho, lazer e celebração, emoldura o quadro dos afetos e paixões entre os sujeitos. É ainda elo identitário, marcando a fronteira entre territórios, grupos e condições. E em momentos de grande tensão social e política, surge como arma de questionamento crítico (como em algumas manifestações do samba carioca ao longo de toda sua história, ou da MPB dos anos 60 e 70 durante os anos do regime de exceção, ou ainda no rap dos dias

* Doutor em Teoria e História Literária pela UNICAMP 
que correm).

Ao mesmo tempo, tornou-se assunto relevante para parte significativa da intelligentsia do país, objeto de investigação acadêmica nos mais variados campos do conhecimento (história, sociologia, antropologia, musicologia, literatura, semiótica, estudos culturais etc.). Revela-se, ainda, objeto de interesse para criadores situados em pontos privilegiados do espectro artístico (p. ex., em músicos "sofisticados", de Tom Jobim a Benjamin Taubkin; no cinema, das ficções de Cacá Diegues aos documentários ou ficcionalizações da vida de compositores e músicos, como nos recentes Cazuza, Os Filhos de Francisco, Viva São João; na dança e na performance, do trabalho de pesquisa e difusão de um Antônio Nóbrega aos projetos experimentais do grupo Corpo; etc.).

Por vezes, atrai a si os tantos esforços de definição e representação de uma identidade nacional, como ocorreu com o samba urbano durante a Era Vargas ou com a MPB dos anos 60/70, com destaque para a canção de protesto ou, na contramão desta, as realizações do Tropicalismo. Este, a despeito das tantas ambiguidades e de uma maior abertura para o internacional, não deixou de postular um lugar de centralidade e representação (ou seja: também propôs, à sua maneira, uma "interpretação do Brasil").

E se podemos desconfiar sempre das tentativas de estabelecer uma identidade nacional (única, coesa, formulada a partir de um centro evidente), não há como negar que, ao olhar estrangeiro, a música popular brasileira, ao lado de uma ou outra manifestação (o futebol, com seus astros e mitos), aparece como encarnação fundamental da "brasilidade" (samba, carnaval, Carmem Miranda, Bossa Nova etc., já tornados clichês pela indústria do entretenimento). Com a exceção de um ou outro filme ou diretor de cinema, ou do fenômeno Paulo Coelho (cuja nacionalidade, ao que tudo indica, não parece ser ingrediente de especial apelo na recepção de sua obra), nenhuma outra manifestação artística do país terá tido a visibilidade fora do Brasil que tem esta manifestação.

O interesse de "boa parte da elite cultural" pela canção popular (ou melhor: por um "certo tipo" de canção) desde a Bossa Nova e seus desdobramentos (aquilo que iria, dos anos 60 em diante, ser chamado abreviadamente de MPB) pode ser claramente conferido a partir de algumas publicações que marcaram época, produzidas por intelectuais pertencentes a diferentes campos da produção cultural.

Em 1968, o poeta Augusto de Campos, protagonista da agitação vanguardista na arte brasileira dos anos 50/60, nome central do movimento de Poesia Concreta, tradutor, ensaísta e um crítico e melômano especialmente interessado nas vertentes mais radicais da música de concerto do século XX (de Anton Webern a John Cage), organizou o pioneiro Balanço da bossa, posteriormente ampliado e rebatizado de Balanço da bossa e outras bossas. Nele, o autor reunia artigos saídos esparsamente na imprensa ao longo da década de 1960, escritos no calor da hora por nomes como Brasil Rocha Brito, Júlio Medaglia, Gilberto Mendes, além de textos seus, artigos a respeito do efervescente cenário da música popular daqueles anos, do surgimento da Bossa Nova de João Gilberto e Tom Jobim ao 
Tropicalismo de Caetano Veloso e Gilberto Gil. $\mathrm{Na}$ "Introdução" do volume, de março de 1968, seu organizador sintetizava nos seguintes termos o perfil dos colaboradores e a perspectiva crítica em comum que os unia então:

Embora escritos em épocas diversas e por autores diversos, esses estudos - de um musicólogo, um regente, um compositor e um poeta "eruditos" mas entusiastas da música popular - têm uma perspectiva comum que os solidariza. Estão, todos, predominantemente interessados numa visão evolutiva da música popular, especialmente voltados para os caminhos imprevisíveis da invenção.

Nesse sentido, estou consciente de que o resultado é um livro parcial, de partido, polêmico. Contra. Definitivamente contra a Tradicional Família Musical. Contra o nacionalismonacionalóide em música. O nacionalismo em escala regional ou hemisférica, sempre alienante. Por uma música nacional universal. (CAMPOS, 2005, p. 14)

Augusto de Campos projetava sobre o campo da música popular conceitos e categorias caros às vanguardas históricas ("visão evolutiva", "invenção") e tomava partido num debate que opunha os defensores de uma "legítima" e "tradicional" música popular brasileira, infensa à influência estrangeira (seja do jazz, seja do rock), bem como à experimentação, aos "modernizadores" dessa mesma música popular (bossa-novistas e tropicalistas). E era ao lado deste último grupo que o poeta "erudito" e de vanguarda vinha, naturalmente, se alinhar. ${ }^{1}$ Tal polarização viria a se desvanecer ao longo dos anos, mas as intervenções críticas presentes no volume marcaram época e certamente ajudaram a sedimentar o lugar de prestígio que compositores como Caetano Veloso e Gilberto Gil, por exemplo, vieram a ocupar junto a um público "mais letrado", público em parte coincidente com aquele atingido pelos meios de comunicação de massa em que a música daqueles circulava, mas não restrito a eles. ${ }^{2}$

Em diferente linha de investigação, outro estudo importante no processo de recepção acadêmica da música popular daqueles anos, agora com destaque para o Tropicalismo, é Tropicália: alegoria, alegria, de Celso Favaretto, originalmente uma dissertação de mestrado em filosofia, apresentada na Faculdade de Filosofia, Letras e Ciências Humanas da Universidade de São Paulo, e publicada em livro em 1979. Mobilizando um amplo leque de conceitos (extraídos da sociologia, da

\footnotetext{
${ }^{1}$ A propósito de tal deslocamento de conceitos da arte de alto repertório para a arte popular, num dos ensaios contidos no mesmo volume, "Viva a Bahia-Ia-Ia!", Augusto de Campos recuperava algumas noções taxonômicas do poeta modernista norte-americano Ezra Pound, além de citar fragmento do poeta futurista russo Vladimir Maiakóvski: "Se formos aplicar a classificação de Pound ("Inventores", "Mestres", "Diluidores" etc.), restritamente, ao quadro atual da música popular brasileira, é possível que a Chico Buarque de Hollanda caiba o título de um jovem "mestre". Mas o risco e a coragem da aventura ("A poesia - toda - uma viagem ao desconhecido", como queria Maiakóvski), estes pertencem a Caetano e Gil, "inventores", como pertenceram antes a Tom [Jobim] e a João [Gilberto]." (CAMPOS, 2005, p. 159-160) Sobre tais conceitos poundianos, consultar ABC da literatura. 2 Sobre as muitas trocas e possíveis aproximações entre a Poesia Concreta e o Tropicalismo, consultar
o volume Convergências, de Lúcia Santaella, estudo já clássico sobre o assunto. Caetano Veloso, no
seu livro de memórias, Verdade tropical, dedica todo um capítulo da Parte 2 do volume, justamente
intitulado "A Poesia Concreta", para tratar da questão, reconhecendo a importância desse diálogo, mas
assinalando os pontos de tensão.
} 
psicanálise, da estética, da linguística, da teoria musical e literária), Favaretto centrava-se numa abordagem geral da intervenção crítico-criativa do Tropicalismo e na análise de canções surgidas nos anos históricos do movimento (entre 1967, com a polêmica entrada em cena de Caetano Veloso e Gilberto Gil defendendo, respectivamente, "Alegria, Alegria" e "Domingo no Parque", no III Festival da Música Popular Brasileira da TV Record de São Paulo; ao disco coletivo Panis et circensis, de 1968, com colaborações, além dos já citados, de Rogério Duprat, Capinam, Torquato Neto, Tom Zé, Gal Costa, Nara Leão e os Mutantes).

No processo de análise, o autor destaca a operação paródica frequente nas canções, bem como o processo de justaposição de elementos arcaicos e modernos, que criam imagens estranhas e tensas, alegorias da própria situação do Brasil e sua inserção no mundo. Passa em revista os tantos diálogos com a Antropofagia de Oswald de Andrade, a Poesia Concreta, a música experimental, a própria tradição da música popular brasileira, e outras manifestações culturais (do cinema de Joaquim Pedro de Andrade ao Teatro Oficina de José Celso Martinez Correia). E aborda, ainda, os tantos embates entre crítica estética e comportamental e crítica social e política, sublinhando a ambígua inserção do movimento na indústria do espetáculo e do consumo.

A certa altura do texto, Favaretto equipara as realizações musicais do grupo à produção cultural geral daquele momento:

(...) o tropicalismo levou à área da música popular uma discussão que se colocava no mesmo nível da que já vinha ocorrendo em outras, principalmente o teatro, o cinema e a literatura. Entretanto, em função da mistura que realizou, com os elementos da indústria cultural e os materiais da tradição brasileira, deslocou tal discussão dos limites em que fora situada, nos termos da oposição entre arte participante e arte alienada. O tropicalismo elaborou uma nova linguagem da canção, exigindo que se reformulassem os critérios de sua apreciação, até então determinados pelo enfoque da crítica literária. Pode-se dizer que o tropicalismo realizou no Brasil a autonomia da canção, estabelecendo-a como um objeto enfim reconhecível como verdadeiramente artístico. (FAVARETTO, 1996, p. 27-28)

Na sequência, o autor toca na questão da canção como gênero específico, para além da música e da literatura: "Por ser inseparavelmente musical e verbal, é difícil tanto compor a canção como analisá-la. Ela remete a diferentes códigos e, ao mesmo tempo, apresenta uma unidade que os ultrapassa (...)." (FAVARETTO, 1996, p. 28). E, mais adiante, indica justamente aquele que será o ponto de partida, em anos subsequentes, para os estudos de Luiz Tatit sobre a canção popular no Brasil (e para além do próprio Tropicalismo): "Os tropicalistas realizaram a vinculação de texto e melodia, explorando o domínio da entoação, o deslizar do corpo na linguagem, a materialidade do canto e da fala, operados na conexão da língua e sua dicção, ligados ao infracódigo dos sons que subjazem à manifestação expressiva." (FAVARETTO, 1996, p. 32) ${ }^{3}$

Nas análises que desenvolve, parece claro que Favaretto dá às canções tropicalistas um estatuto que as põe em pé de igualdade com outras manifestações da arte de 
alto repertório, reconhecendo-as como passíveis de análises estéticas sofisticadas e em sintonia com as grandes questões da cultura e da sociedade de seu tempo. Do mesmo ano de 1979, é o ensaio "O Minuto e o Milênio ou Por Favor, Professor, Uma Década de Cada Vez", de José Miguel Wisnik, escrito originalmente para o volume Música, da coleção Anos 70, dirigida por Adauto Novaes. Neste breve (posto que concentrado) estudo, Wisnik discute a produção de música popular ao longo da década de 1970 no Brasil, centrando o foco, a certa altura, em alguns nomes centrais da canção brasileira, surgidos na década imediatamente anterior e que consolidaram sua trajetória por aqueles anos, como Roberto Carlos, Caetano Veloso e Chico Buarque de Holanda.

Tomando como ponto de partida o chamado "vazio cultural" vivido então, para o qual duas realidades contribuíam especialmente - o crescimento dos meios de comunicação de massa e a censura à produção artística durante o Regime Militar - , o autor procurava evidenciar de que modo a música popular, por meio de uma espécie de "poética da malandragem", conseguia driblar a censura política e de costumes e resistir à simples e pura padronização imposta pela indústria do entretenimento.

Segundo Wisnik, dois modos de produção musical conviviam e se interpenetravam então no país: o "industrial", intensificado com o crescimento da indústria do disco e dos meios de comunicação; e o "artesanal", "que compreende os poetas-músicos criadores de uma obra marcadamente individualizada, em que a subjetividade se expressa lírica, satírica, épica e parodicamente." (WISNIK, 2004, p. 169) Nesse lugar limítrofe, conceitos como os da Escola de Frankfurt utilizados para entender a produção da "indústria cultural", como "estandardização" e "regressão da audição", se mostrariam insuficientes:

A má vontade para com a música popular em Adorno é grande. Podemos entendê-la num europeu de formação erudita. Por um lado, o uso musical para ele é a escuta estrutural estrita e consciente de uma peça, a percepção da progressão das formas através da história da arte e através da construção de uma determinada obra. Por outro, o equilíbrio entre a música erudita e a popular, num país como a Alemanha, faz a balança cair espetacularmente para o lado da tradição erudita, porque a música popular raramente é penetrada pelos setores mais criadores da cultura, vivendo numa espécie de marasmo kitsch e digestivo (...).

Ora, no Brasil a tradição da música popular, pela sua inserção na sociedade e pela sua vitalidade, pela riqueza artesanal que está investida na sua teia de recados, pela sua habilidade em captar as transformações da vida urbano-industrial, não se oferece simplesmente como um campo dócil à dominação econômica da indústria cultural que se traduz numa linguagem estandardizada, nem à repressão da censura que se traduz num controle das formas de expressão política e sexual explícitas, nem às outras pressões que se traduzem nas exigências do bom gosto acadêmico ou nas exigências de um engajamento

\footnotetext{
${ }^{3}$ Entre os muitos estudos publicados por Luiz Tatit, trabalhos sem dúvida centrais na sua produção são O cancionista: composição de canções no Brasil e O século da canção.
} 
Wisnik insiste nos usos da música no país, entre os quais o puramente "estéticocontemplativo" (fundamental dentro da tradição culta européia) nunca se impôs. No Brasil, a música erudita nunca teria conseguido formar plenamente um "sistema" (no sentido que Antonio Candido dá para o termo no seu Formação da literatura brasileira), congregando autores, obras e público. Aqui, a música sempre teria estado fortemente vinculada às práticas rituais e mágicas, às atividades do cotidiano, às festas populares etc. Com o processo de urbanização ao longo do século XX e com o advento dos meios de massa, tais usos iriam amplificar-se e complicar-se ainda mais.

O autor sublinha o caráter impuro, híbrido, miscigenado da produção musical brasileira, e dos problemas que surgem na sua compreensão:

O fenômeno da música popular brasileira talvez espante até hoje, e talvez por isso mesmo também continue pouco entendido na cabeça do país, por causa dessa mistura em meio à qual se produz: a) embora mantenha um cordão de ligação com a cultura popular nãoletrada, desprende-se dela para entrar no mercado e na cidade; b) embora se deixe penetrar pela poesia culta, não segue a lógica evolutiva da cultura literária, nem se filia a seus padrões de filtragem; c) embora se reproduza dentro do contexto da indústria cultural, não se reduz às regras da estandardização. Em suma, não funciona dentro dos limites estritos de nenhum dos sistemas culturais existentes no Brasil, embora se deixe permear por eles. (WISNIK, 2004, p. 178)

Wisnik evidenciava assim o lugar limítrofe, privilegiado e problemático ocupado pela canção popular no Brasil àquela altura. A partir da definição desse lugar ("um lugar entre"), pode-se compreender melhor por que motivo algumas canções de apelo popular, veiculadas no rádio e na televisão para o consumo de massa, poderiam surgir também como local de debates estéticos, sociais e políticos, e interessar fortemente ao mundo letrado. ${ }^{4}$

No início dos anos 80, a Editora Abril Cultural lançava a série Literatura Comentada, com pequenos volumes dedicados a nomes fundamentais da literatura brasileira do passado e do presente, com informações biobliográficas e apreciações críticas da parte dos seus organizadores, bem como uma antologia de textos dos escritores escolhidos. Entre os autores àquela altura mais recentes, além do já consagrado Vinicius de Moraes (nome de trânsito evidente entre o mundo literário e o da canção popular), iria dedicar volumes específicos a Chico Buarque de Holanda, Caetano Veloso e Gilberto Gil. ${ }^{5}$ Se o primeiro destes três, ao lado do trabalho com música, havia enveredado pela novela de ficção (Fazenda modelo) e pelo teatro (Calabar, Gota d'água e Ópera do malandro), os dois últimos

\footnotetext{
${ }^{4}$ Outros três volumes escritos àquela roda por nomes importantes do meio universitário brasileiro e que dão amplo destaque para a música popular dentro da produção cultural são Música popular: de olho na fresta, de Gilberto Vasconcelos (1977); Música popular e moderna poesia brasileira, de Affonso Romano de Sant'Anna (1978); Impressões de viagem: CPC, vanguarda e desbunde - 1960/70, de Heloísa Buarque de Hollanda (1980).
} 
eram fundamentalmente compositores de canções. Tratava-se, vale lembrar, de uma série que circulava em bancas de jornais e revistas, voltada, portanto, para o grande público, especialmente sensível aos apelos de nomes de maior visibilidade nos meios de comunicação. Por outro lado, não deixava de ser uma espécie de "canonização" precoce de tais criadores, sua incorporação ao universo da "literatura" (da cultura séria e letrada, portanto). De qualquer forma, parece evidente que tais artistas da canção (e não quaisquer outros, como Roberto e Erasmo Carlos, por exemplo) rasuravam os limites entre os campos, podendo ser reivindicados por este ou aquele, a depender dos critérios de avaliação (os mesmos nomes integravam a série Nova história da música popular brasileira, de alguns anos antes e pela mesma editora, publicação com fascículo e disco de vinil em anexo, igualmente com ampla circulação nas bancas). ${ }^{6}$

\section{Paulo Leminski: música popular e literatura}

É dentro desse quadro que se pode entender melhor os interesses de Paulo Leminski pela canção popular brasileira ao longo de sua trajetória literária. Um estudo de maior fôlego sobre seu trabalho como compositor e letrista ainda está por ser feito. ${ }^{7} \mathrm{O}$ que se pretende abordar a seguir é o modo como o escritor curitibano percebia certa música popular produzida à sua época, como ele avaliava o papel de alguns nomes significativos da produção musical do período e de que maneira a própria música surgia como orientação e assunto em sua obra, especialmente na poesia.

As trocas entre música (canção) popular e literatura no Brasil atravessam o século XX. Vinicius de Moraes será sempre lembrado como um nome fundamental, de atuação vigorosa nos dois campos, ponto de referência e partida para tantos letristas e poetas-letristas subsequentes. Mas, antes dele, outros transitaram da música para a literatura (ou vice-versa), como Catulo da Paixão Cearense e Orestes Barbosa, por exemplo, que escreveram letras para canções memoráveis

\footnotetext{
${ }^{5}$ Noel Rosa, único dentre os compositores da "Velha Guarda", iria receber igualmente um fascículo dedicado à sua produção.

${ }^{6} \mathrm{Em}$ anos recentes, Chico Buarque enveredou de vez pela prosa de ficção (com os romances Estorvo, Benjamim, Budapeste e Leite derramado), de modo que sua inserção no campo da literatura é coisa inequívoca. Quanto a Caetano Veloso, a incorporação de seu nome dentro da Antologia comentada da poesia brasileira do século 21, organizada pelo crítico Manuel da Costa Pinto, não deixa de ser curiosa e sinal de que esse lugar que o compositor veio a ocupar desde os anos 70 permanece mais ou menos intocado. Há outros autores dentro dessa mesma antologia cuja obra transita entre a poesia e a canção, como por exemplo Hermínio Bello de Carvalho, Antonio Cícero, Paulo Neves, Waly Salomão e Rodrigo Garcia Lopes, mas Caetano é o único que teve letras de canção ("Tropicália", "Fora da Ordem" e "Livros"), e não poemas, inseridos no volume. O organizador justifica sua presença nos seguintes termos: "Caetano Veloso é autor de clássicos da música popular que aspiram à incorporação ao cânone da poesia brasileira. Sempre será polêmica a questão de decidir quais de suas letras musicais podem ser lidas de modo autônomo, como artefatos estritamente literários ou mesmo decidir se essa questão se coloca. O que não parece estar em questão é sua importância na continuação das poéticas que surgiram antes dele, ao final dos anos 1950. (...)" (PINTO, 2006, p. 363) Se suas canções "aspiram à incorporação ao cânone da poesia brasileira" ou não é questão controversa. O fato é que o crítico as incorpora, e dá motivos para fazê-lo, motivos que poderiam, aliás, justificar a presença de outro nome, Gilberto Gil, que ficou de fora da antologia.
}

7 Um dos raros estudos é "No corpo da voz: a poesia-música de Paulo Leminski", do poeta Ricardo Aleixo. Sobre o papel da música popular em Leminski, redigi há uns bons anos já o artigo "Nalgum lugar entre o experimentalismo e a canção popular: as cartas de Paulo Leminski a Régis Bonvicino". 
do cancioneiro brasileiro e desenvolveram, igualmente, carreira como escritores. ${ }^{8}$ Mário de Andrade deixou sempre claro seu grande interesse pela cultura popular (especialmente pelas manifestações mais tradicionais, menos tocadas pelo ambiente urbano). E Manuel Bandeira teve muitos poemas seus musicados, tanto por compositores eruditos quanto populares, além de ter escrito letra para alguma música, e revelar, em muitas de suas crônicas, interesse pela música brasileira, seus gêneros, criadores e intérpretes. ${ }^{9}$

No entanto, os poetas canônicos de boa parte do século XX (com exceção de Bandeira e sobretudo Vinicius) são essencialmente poetas do livro, poetas-poetas, não-letristas: Oswald de Andrade, Drummond, Murilo Mendes, Jorge de Lima, Cecília Meireles, João Cabral, Ferreira Gullar, Augusto e Haroldo de Campos etc. O quadro parece mudar a partir de fins dos anos 50, e não por acaso a partir da Bossa Nova e de Vinicius de Moraes. Alguns nomes significativos da poesia e da literatura do final do século XX no Brasil tiveram forte ligação com a produção de canções, sobretudo como letristas: Torquato Neto, Capinam, Jorge Mautner, Wally Salomão, Cacaso, Antonio Cicero, Geraldo Carneiro, Paulo Leminski, Alice Ruiz, Arnaldo Antunes etc.

Leminski, portanto, não é exceção. Pelo contrário, confirma toda uma tendência geral da época, de ruptura de limites entre a arte culta e a arte popular e de massa, entre a poesia informada e a letra de canção, entre a experimentação formal e o desejo de comunicação. Produz sua obra a partir de certas coordenadas, que delimitam um campo de boa tensão interna, coordenadas que vão da Poesia Concreta, passam pela Contracultura internacional (sobretudo na sua vertente anglo-americana: beat generation, hippies, rock) e chegam à expressão dessa mesma Contracultura em termos brasileiros, com o Tropicalismo e o Póstropicalismo. Nesse campo, a música popular surge como gênero da maior importância, seja como objeto de fruição e referência estéticas, seja como lugar de atuação criativa.

Numa carta ao antropólogo e poeta Antônio Risério, datada de 1975 (provavelmente o primeiro contato epistolar entre os dois), o escritor curitibano registrava:

muito interessado nisso que parece ser a post-literatura entre nós: textos/semioses, malditos a todos os títulos.

traços: estruturas concretas + pirações psicodélicas + desvarios tropicais + sei lá o quê. localização: entre São Paulo e/\&/ Bahia.

característica: música no centro.

o trabalho de gil, caetano, gal, macalé, duda, capinam, waly (não esquecer o roque Mutantes/Rita Lee, via Duprat, mais um casamento sul/norte, eletrônico/Amaralina, Rita: "Serginho e Arnaldo deram dicas de guita para Gil e aprendemos com os baianos a

\footnotetext{
8 Sobre o assunto, conferir a tese de doutorado de Benito Rodriguez, Luar da cidade, sertão de neon: literatura e canção nas obras de Catulo da Paixão Cearense e Orestes Barbosa, defendida na USP em 1998.

${ }^{9}$ A esse respeito, conferir Itinerário de pasárgada, de Manuel Bandeira, autobiografia intelectual do poeta.
} 
musicalidade da língua portuguesa").

muito interessado nisso de post-literatura.

(DICK e CALIXTO, 2004, p. 363)

Importante destacar essa idéia de uma "post-literatura", que parece englobar qualquer produção textual criativa para além do suporte "livro" (sobretudo o livro como produto industrial, o meio de veiculação da produção literária na Modernidade), bem como dos tradicionais espaços de inserção e validação dos artistas da palavra (o mercado editorial, a crítica literária, a universidade). Tratase, numa mão, de um "flerte" com a produção dos poetas marginais do período ("malditos a todos os títulos"); e noutra, sobretudo, na valorização da canção como espaço propício e legítimo para a criação - e criação verbal.

Em outra carta do escritor curitibano, agora endereçada ao então jovem poeta paulistano Régis Bonvicino (carta datada de 6 de novembro de 1978), surge uma formulação que se conecta com a anterior:

tenho dois neutralizadores da literatura (2 anti-ambientes:

- música popular / composição

- publicidade / lay-out / arte.

(LEMINSKI e BONVICINO, 1999, p. 120) ${ }^{10}$

Outra vez aqui a palavra "literatura" vem impregnada de sentidos negativos. Tratase de ir além da "literatura" (no sentido cristalizado do termo), procurar estímulos de criação e espaços de circulação fora dos meios literários mais tradicionais.

Por aquela época, posteriormente à publicação do Catatau (1975), Paulo Leminski havia se envolvido bastante com a publicidade como opção profissional, e o contato com artistas gráficos vinha ao encontro de suas próprias investigações no campo da poesia informada pelo Concretismo. Por aqueles anos, seu trabalho como cancionista também se intensificara, seja nas composições individuais, seja nas parecerias, especialmente com os curitibanos Ivo Rodrigues e Marinho Gallera. As cartas a Bonvicino documentam ainda os encontros com músicos e compositores populares de passagem por Curitiba (Gilberto Gil, Caetano Veloso, Gal Costa, Jorge Mautner, Jards Macalé, Tom Zé, Lucinha Turnbull), e o caráter positivo dessa interlocução. ${ }^{11}$

O papel da canção popular e de alguns dos seus principais nomes àquela altura fica ainda inequivocamente explicitado em alguns depoimentos do escritor, como nesta entrevista para Almir Feijó, no mesmo ano de 1978:

(...) na nossa geração o centro da poesia se deslocou do livro pra música popular. Com a geração que produziu Caetano e Chico Buarque, viu se deslocar o pólo da poesia, do

\footnotetext{
${ }^{10}$ Aprofundei uma discussão desses tópicos no artigo "Nalgum lugar entre o experimentalismo e a canção popular".

${ }^{11}$ Sobre a vida de Leminski, consultar a biografia Paulo Leminski: o bandido que sabia latim, de Toninho Vaz.
} 
suporte livro pro suporte disco. De repente os dois poetas da nova geração não estão editando livros. São músicos que fazem letras e estão gravando discos. Realmente, não existe nenhum poeta escrito que você possa contrapor a Caetano e Chico na música popular. Com Caetano e Chico aconteceu uma coisa na música brasileira. Uma coisa muito grande, uma mudança de códigos. E isso prosseguiu. A associação entre poesia e música tende a se tornar cada vez maior em termos de Brasil. Os poetas mais bem dotados, mais talentosos vêm, pelo menos, prestando muita atenção na poesia dos letristas da música popular. (LEMINSKI, 1994, p. 28)

Noutro depoimento, de meados dos anos 80 , um terceiro nome vem se somar aos dois já referidos: "Os três grandes poetas que a minha geração (tenho 40 anos agora) produziu são para mim Caetano Veloso, Gilberto Gil e Chico Buarque." (LEMINSKI, 1985, p. 23)

A consideração dos limites formais e pragmáticos entre canção e poesia é assunto controverso, e só recentemente tem recebido tratamento teórico adequado. Celso Favaretto, em passagem atrás abordada, fazia questão de sublinhar a "autonomia da canção" tropicalista frente a outras manifestações, o seu estatuto de "objeto artístico" diferenciado. Boa parte da produção acadêmica de Luiz Tatit, a partir de modelos oriundos da Semiótica, destina-se a investigar esse caráter autônomo da canção popular diante da música e da literatura, a despeito de sua clara vinculação ao verbal e ao sonoro. As formulações do escritor curitibano têm, portanto, muito de frase de efeito, muito de provocação, e antes de elidir, de fato, as fronteiras entre os gêneros "canção" e "poesia", parecem indicar a existência de trocas várias entre eles, e, mais do que isso, reconhecer o papel referencial da música popular àquela altura para os autores mais estritamente ligados ao universo literário.

Além de meio para a criação, na passagem dos anos 70 para os 80 , a música popular se afigura a Leminski como estratégia clara de inserção de sua produção num contexto mais amplo. Em outra carta a Bonvicino, sem data, mas ao que tudo indica do ano de 1979, o escritor comenta recentes encontros com Gil e Caetano, e o desejo deste último de gravar a canção "Verdura" (efetivamente gravada no LP Outras palavras, de 1981), para grande satisfação do poeta. E conclui: "minha passagem para a MPB está para se completar: operação mass-mídia". (LEMINSKI e BONVICINO, 1999, p. 156)

De fato, a partir do início dos anos 80, o escritor verá canções suas, só e em parceria, gravadas por nomes de maior ou menor projeção na música popular brasileira, como o já citado Caetano Veloso, Paulinho Boca de Cantor, Moraes Moreira, Blindagem, A Cor do Som, Itamar Assumpção, Guilherme Arantes, MPB4, Ângela Maria, entre outros. Nos mesmos anos 80 , sua poesia começa a circular de modo mais amplo, agora sob a chancela da Editora Brasiliense, que publica Caprichos e relaxos (1983), Distraídos venceremos (1987) e o póstumo La vie en close (1991). Assim, por um lado, a maior presença de material seu no rádio, no show e no disco alicerça sua visibilidade como escritor; e, em contrapartida, seu crescente prestígio como poeta, tradutor e crítico chama a atenção para essa sua outra faceta criativa, numa espécie de círculo que se retroalimenta. 
Mas dentro da produção literária restritamente voltada para o meio impresso, também a música popular tem presença relevante, como uma rápida apreciação dos seus três livros saídos pela Brasiliense revela.

Logo no texto introdutório de Caprichos e relaxos, o poeta explicita a gama dentro da qual, a seu ver, sua poesia se realiza, bem como o papel do leitor em sua variada recepção:

Aqui, poemas para lerem, em silêncio,

O olho, o coração e a inteligência.

Poemas para dizer, em voz alta.

E poemas, letras, lyrics, para cantar.

Quais, quais, é com você parceiro.

(LEMINSKI, 1983, p. 8)

Vale lembrar que este primeiro volume de poesia por uma grande editora, além de poemas mais recentes, reunia parte significativa da produção do escritor realizada nas duas décadas anteriores, desde suas experimentações mais marcadamente visuais nas páginas da Revista Invenção, do grupo concretista de São Paulo, ao longo dos anos 60, até aqueles textos publicados nos volumes não fosse isso e era menos / não fosse tanto e era quase e Polonaises, de circulação restrita a Curitiba, saídos em 1980. Tratava-se de material bastante heterogêneo, com poemas visuais ao lado de haicais; epigramas e poemas-piada ao lado de outros um pouco mais extensos, de versos polimétricos e linguagem coloquial; além de alguns textos escritos rente à prosa. O autor, sem reproduzir o título, incluía ainda o texto da letra da canção "Verdura", gravada um pouco antes tanto por Caetano Veloso quanto pelo grupo curitibano Blindagem, numa sugestão de que não reconhecia claros limites entre poema e letra de música. Uma rápida passagem por poemas de Caprichos e relaxos revela a presença da música popular em vários deles, sobretudo referências a alguns ícones do rock anglo-americano e músicos brasileiros caros e próximos a Leminski.

Num poema todo escrito em inglês, à maneira de fragmento de uma protest song de sabor tipicamente sessentista, cita-se canção de Lennon \& McCartney, "Strawberry Fields Forever", do LP dos Beatles Magical mystery tour (1967):

business man

make as many business

as you can

you will never know

who $i$ am

your mother

says no

your father

says never 
you'll never know

how the strawberry fields

it will be forever

(LEMINSKI, 1983, p. 29)

Logo adiante, em poema sem título, numa espécie de prédica endereçada ao deus "Dia", Caetano Veloso figura ao lado do cineasta Glauber Rocha e do poeta e semioticista Décio Pignatari:

dia

dai-me

a sabedoria de caetano

nunca ler jornais

a loucura de glauber

ter sempre uma cabeça cortada a mais

a fúria de décio

nunca fazer versinhos normais

(LEMINSKI, 1983, p. 58)

Em "féretro para uma gaveta", Jimi Hendrix surge referido ao lado de dois nomes axiais da modernidade literária: "esta gaveta do vício / rimbaud tinha uma / muitas hendrix / mallarmé nenhuma". (LEMINSKI, 1983, p. 68)

Em "riso para gil", além da homenagem ao compositor baiano, o poeta cita verso de conhecida canção de Bob Marley, "No Woman No Cry", celebrizada em versão para o português pelo mesmo Gil em contexto brasileiro no final da década de 1970 ("Não Chore Mais"): "everything is gonna be allright". (LEMINSKI, 1983, p. 82) E noutro poema logo adiante, um simples brinquedo verbal, nova referência a Gilberto Gil, agora por intermédio da canção e do LP homônimo Realce (1979), o mesmo que trazia a versão da canção de Marley: "QUE TAL SE / FOSSE REAL / ESSE REALCE / QUE GIL SE / VIU VIAJOU / SE VIA GIL?" (LEMINSKI, 1983, p. 92)

Em outro poema em inglês, paródia de uma letra ou refrão de rock, surge a referência a uma conhecida canção de Jagger \& Richards, "It's only Rock'n'Roll (But I like I)", de LP homônimo dos Rolling Stones de 1974:

it's only life

but I like it

let's go

baby

let's go 
this is life

it is not

rock and roll

(LEMINSKI, 1983, p. 96)

E noutro brinquedo verbal, de sabor bem trocadilhesco, nova referência a nome importante da cena musical brasileira, agora numa contraposição entre literatura e canção popular, com vantagem para a segunda:

tudo
que
li
me irrita
quando
ouço
rita
lee

(LEMINSKI, 1983, p. 123)

Ainda outros poemas se referem à música popular, como "desmontando o frevo" (p. 16), ou este outro, em que o despojamento de certo tipo de canção revela-se como aspiração para o poeta: "à pureza com que sonha / o compositor popular // um dia poder compor / uma canção de ninar". (LEMINSKI, 1983, p. 96)

Nos livros seguintes, as referências são bem menos frequentes. Mas não deixa de ser eloquente a dedicatória de Distraídos venceremos, endereçada a poetas de sua geração que são também letristas (Alice Ruiz e Antonio Cicero), a um poetacompositor-letrista (Arnaldo Antunes), e a um compositor igualmente habilidoso no trato das palavras (Itamar Assumpção): "Em direção a Alice, / cúmplice nesse crime de lesa-vida / chamado poesia. / Para Antonio Cicero, Arnaldo "Titã" Antunes / e - sobretudo - para Itamar Assumpção." (LEMINSKI, 1987, p. 5)

No mesmo livro, no poema "Diversonagens Suspersas", o poeta parodia a "Canção do Expedicionário", em rápida digressão metaliterária: "Por mais prosas que eu perverta, / não permita Deus que eu perca / meu jeito de versejar." (LEMINSKI, 1987, p. 83)

Em La vie en close, no poema "Limites ao Léu", arrola-se conhecidas definições de poesia por diferentes autores - filósofos, poetas e críticos do meio da alta cultura quase todos (Dante, Maiakóvski, Ezra Pound, Goethe, Jakobson, Paul Valéry, Heidegger, Novalis, Coleridge, Wordsworth, Alfred de Vigny, Mallarmé, RicardoReis/Fernando Pessoa, Mathew Arnold, Sartre, Octavio Paz, Décio Pignatari, García Lorca, Roberto Frost), com exceção de um dos nomes centrais da música 
pop norte-americana, Bob Dylan, e sua definição: "poetry is to inspire". A lista se fecha com uma formulação do próprio Paulo Leminski, certamente desejoso de adentrar em tal panteão: "a liberdade da minha linguagem". (LEMINSKI, 1991, p. 10)

E finalmente, no mesmo livro, um haicai sintetiza bem o papel da música para Leminski: "nu como um grego / ouço um músico negro / e me desagrego". (LEMINSKI, 1991, p. 151)

O "grego" remete à tradição européia, culta, letrada, erudita, clássica. O vocábulo "nu" propõe justamente o ideal da beleza entre os gregos antigos, o corpo masculino despido, representado amiúde nas artes. A nudez aqui também pode ter o sentido de desvelamento, de despojamento, de entrega (inclusive erótica), ou ainda indicar a própria circunstância em que o "eu" do poema se encontra no momento em que a música o surpreende, em plena intimidade. O "negro", por sua vez, remete à tradição africana, afro-brasileira, afro-americana, à cultura popular, à música popular, ao samba, ao blues, ao jazz. Trata-se, justamente, de um "músico negro", que surge como um "outro" em relação ao "eu", e que age incisivamente sobre ele, alterando radicalmente seu estado original.

"Grego" e "negro" são vocábulos de sonoridades afins, nos sons vocálicos e nas combinações consonantais. Estabelecem uma rima toante, o que, curiosamente, instaura a semelhança no próprio âmago da diferença. O verbo em primeira pessoa ao final do poema, que indica as consequências da aproximação entre os dois termos, ou melhor, da ação do segundo sobre o primeiro, traz em seu bojo a palavra "grego", que por sua vez trazia a palavra "ego", posto que com o "ê" ainda fechado. Mas o "ego" latente em "grego" ficará evidente agora no "é" aberto do verbo "desagrego", que conclui o poema. O movimento descendente da língua dentro da boca na passagem do som fechado para o aberto como que iconiza a ação que se representa aí (o vir abaixo, o desmontar-se, o desagregarse). É o próprio "eu" ("ego") o que se "desagrega", e esse movimento acontece paralelamente no plano dos sons e dos sentidos.

A aproximação de elementos a princípio antitéticos é operação cara ao autor, como o título de um de seus mais conhecidos livros, Caprichos e relaxos, de imediato evidencia. Em clave autobiográfica, Leminski sempre fez questão de sublinhar sua origem miscigenada, européia e africana - "mestiço de polaco com negro", como reza o pequeno texto "Sobre o Autor", presente ao final de todos os seus livros de poemas pela Brasiliense.

O haicai em questão acaba por se configurar também como uma espécie de miniatura que concentra em si um motivo ou assunto que o escritor já tratara caudalosamente num dos livros que Ihe fez a fama como prosador experimental, o Catatau (1975). Vale lembrar que lá Leminski imaginava a vinda do filósofo René Descartes ao Brasil, acompanhando Maurício de Nassau, na $1^{a}$ metade do século XVII, durante a Invasão Holandesa. Em Olinda/PE, Descartes (ou Renatus Cartesius, no nome alatinado que está no livro) fuma maconha e observa, através de uma luneta, em delírio alucinatório, a fauna e a flora brasileiras num horto que Nassau mandara construir. O filósofo da razão perde a razão por intermédio 
do alucinógeno e do contato com a exuberante natureza dos trópicos, elementos que subvertem as categorias do seu pensamento. A linguagem se desarticula, mimetizando os processos mentais do mesmo filósofo. Trata-se, em boa medida, do "grego" que se "desagrega" do haicai em questão.

Mas neste é a música (e a música negra, e não qualquer outra) o que tem o poder de desestabilizar o pensamento e a razão, de desmontar o ego (e eventualmente a própria noção de subjetividade), portanto de pôr em xeque uma certa tradição ocidental (se se quiser insistir nessa possível conexão com o Catatau).

Voltando ao texto de José Miguel Wisnik, trata-se menos de uma fruição "estéticocontemplativa" a que se representa aqui, como na música de concerto de extração européia, e mais de uma fruição "mágico-ritualística", que põe o corpo no centro da cena. É ele que sofre a ação desse tipo de música, vigorosamente, e se transforma. A música, assim, acaba por vincular-se diretamente à sensação, ao sentimento, à emoção (muito mais do que à razão). O eu que se desagrega é certamente o do sujeito que sente e se emociona com o que ouve. Inevitável não lembrar de um breve poema do autor: "prazer / da pura percepção / os sentidos / sejam a crítica / da razão". (LEMINSKI, 1987, p. 57)

Num depoimento de 1985 (uma conversa entre Paulo Leminski, Guilherme Mansur, Alice Ruiz e Otávio Ramos, publicada em Poesia livre), o autor, numa visada diacrônica, procurava explicitar a transformação da sua obra ao longo do tempo, da visualidade fortemente influenciada pelo Concretismo no início da carreira à maior discursividade de sua poesia posterior. São formulações bastante agudas sobre o papel da voz e do canto em sua produção, e soam como bom acorde no desfecho deste artigo:

Durante muito tempo, escrevi no espaço, no espaço branco da página, a página do livro, da revista, a página do pôster. Agora, eu poeto no tempo, na substância fugaz da voz, na música, na cadeia de sons da vida. Sobretudo, no corpo da voz, essa coisa quente que sai de dentro do corpo humano, para o beijo ou para o grito de guerra. (...) (DICK e CALIXTO, 2004, p. 290-291)

\section{Referências bibliográficas:}

ALEIXO, Ricardo. "No corpo da voz: a poesia-música de Paulo Leminski". In: DICK, André e CALIXTO, Fabiano (orgs.). A linha que nunca termina: pensando Paulo Leminski. Rio de Janeiro: Lamparina, 2004.

BANDEIRA, Manuel. Itinerário de pasárgada. $3^{a}$ ed. $8^{a}$ imp. Rio de Janeiro: Nova Fronteira; Brasília: 1984.

CAMPOS, Augusto de. Balanço da bossa e outras bossas. $2^{a}$ reimpr. da $5^{a}$ ed. de 1993. São Paulo: Perspectiva, 2005. (Coleção Debates, vol. 3)

DICK, André e CALIXTO, Fabiano (orgs.). A linha que nunca termina: pensando Paulo Leminski. Rio de Janeiro: Lamparina, 2004.

FAVARETTO, Celso. Tropicália: alegoria, alegria. 2a ed. rev. São Paulo: Ateliê Editorial, 1996. 
HOLLANDA, Heloísa Buarque de. Impressões de viagem: CPC, vanguarda e desbunde - 1960/70. 3a ed. Rio de Janeiro: Rocco, 1992.

LEMINSKI, Paulo. Catatau. Curitiba: Grafipar. 1975.

. Caprichos e relaxos. 3a ed. São Paulo: Brasiliense, 1985.

. Um escritor na biblioteca. Curitiba: Biblioteca Pública do Paraná, 1985.

Distraídos venceremos. São Paulo: Brasiliense, 1987.

. Paulo Leminski. Série Paranaenses no 2. Curitiba: Scientia et Labor, 1988.

La vie en close. São Paulo: Brasiliense, 1991.

LEMINSKI, Paulo e BONVICINO, Régis. Envie meu dicionário: cartas e alguma crítica. Organização de Régis Bonvicino, com a colaboração de Tarso M. de Melo. São Paulo: Ed. 34, 1999.

PINTO, Manuel da Costa. Antologia comentada da poesia brasileira do século 21 . São Paulo: Publifolha, 2006.

POUND, Ezra. Abc da literatura. Trad. de Augusto de Campos e José Paulo Paes. 5a Ed. São Paulo: Cultrix, 1986.

RODRIGUEZ, Benito Martinez. Luar da cidade, sertão de neon: literatura e canção nas obras de Catulo da Paixão Cearense e Orestes Barbosa. São Paulo, 1998. Tese de doutorado. USP - FFLCH.

SANDMANN, Marcelo. "Nalgum lugar entre o experimentalismo e a canção popular: as cartas de Paulo Leminski a Régis Bonvicino". Revista Letras. Curitiba: Editora da UFPR, $n^{\circ} 52,2^{\circ}$ semestre de 1999.

SANTAELLA, Lúcia. Convergências: poesia concreta e tropicalismo. São Paulo: Nobel, 1986.

SANT'ANNA, Affonso Romano de. Música popular e moderna poesia brasileira. $3^{a}$ ed. Petrópolis: Vozes, 1986.

TATIT, Luiz. O cancionista: composição de canções no Brasil. São Paulo: EDUSP, 1996.

. O século da canção. Cotia, SP: Ateliê Editorial, 2004.

TATIT, Luiz e LOPES, Ivã Carlos. Elos de melodia e letra: análise semiótica de seis canções. Cotia, SP: Ateliê Editorial, 2008.

VASCONCELOS, Gilberto. Música popular: de olho na fresta. Rio de Janeiro: Graal, 1977.

VAZ, Toninho. Paulo Leminski: o bandido que sabia latim. Rio de Janeiro, São Paulo: Record, 1991.

VELOSO, Caetano. Verdade tropical. São Paulo: Companhia das Letras, 1997. WISNIK, José Miguel. "O Minuto e o Milênio ou Por Favor, Professor, Uma Década de Cada Vez". In: . Sem receita: ensaios e canções. São Paulo: Publifolha, 2004. 


\section{Abstract:}

Taking the work of the Curitiban writer Paulo Leminski as example, this paper investigates the place occupied by popular music in Brazilian culture in the last decades of the 20th century. Also, it investigates some relations of popular music with the literary production of the period.

\section{Keywords:}

Paulo Leminski, Brazilian Popular Music, Brazilian Poetry.

Recebido em 15/05/2009. Aprovado em 01/06/2009. 